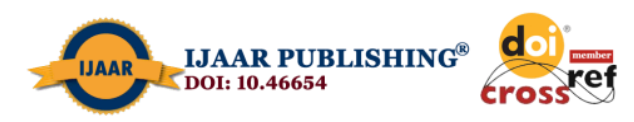

International Journal of Advanced Academic Research | ISSN: 2488-9849

Vol. 7, Issue 5 (May, 2021) | www.ijaar.org

Journal DOI: www.doi.org/10.46654/ij.24889849

Article DOI: www.doi.org/10.46654/ij.24889849.s7557

\title{
ECOWAS FREE MOVEMENT PROTOCOL DURING A PANDEMIC: AN ASSESSMENT
}

\author{
IYANUOLUWA .F. OLANIYI \\ M.sc Student \\ Babcock University Ilishan-Remo Ogun State \\ Department Of Political Science \\ iyanuo3009@gmail.com
}

\begin{abstract}
West African states have been gravely affected since the outbreak of the dreaded COVID-19 pandemic began. The socio-economic and political aspects of ECOWAS have been affected because most African states have not been able to curtail the virus and a cure has not yet been found. Therefore, economic activities were suspended for a while, but now states are getting and creating ways by which they could work around the global issue they face because things cannot return to the way they werebefore the virus. The paper focuses on the free movement protocol implemented by the Economic Community of West African States (ECOWAS) and how the pandemic has affected its activities, how flexible the protocol has been, and how they adapt to the new normal. This paper however, is based solely on secondary sources of data. This paper concludes that due to the corona virus, ECOWAS had to ban the free movement of persons and free trade due to the lack of a conducive end safe environment. This paper notes that West African states under ECOWAS are losing funds due to the ban, and this has been affecting their development.
\end{abstract}

Keywords: ECOWAS, COVID-19, West Africa, boarders, Free Movement 
Journal DOI: www.doi.org/10.46654/ij.24889849

\section{Introduction}

The free movement protocol is a law created by ECOWAS in 1979 to promote integration between West African states. These states are also referred to as a community or member states. In the protocol, people within the West African community are free to travel within boundaries and have the right to reside in any state of their choice for ninety days without a visa. Also, member states can communicate freely and trade goods across borders.

The Economic Community of West African States (ECOWAS) was set up on May 28, 1975through the Treaty of Lagos, to encourage a typical financial space for West Africans. The ECOWAS Commission contains 15 member states: Ghana, Niger, Senegal, Mali, Guinea Conakry, the Republic of Benin, Guinea Bissau, Nigeria, Burkina Faso, Cape Verde, Cote d'Ivoire, Togo, Sierra Leone, Liberia, and Gambia. After four years, in 1979, the Commission's Protocol on Free Movement was considered as an instrument to empower free development of ECOWAS residents inside the sub-locale. This protocol was projected as a basic piece of financial space where residents can profit and member states can gain assets (Adeniran, 2012.).

European states turned their borderlands into military regions where combat was rehearsed regularly and eventually took place (Brunet-Jailly 2010). Artificial borders made in the late nineteenth century following the scramble for Africa were a result of colonization by external forces, these boundaries were created with little consideration for local or ethnic legacy. Thus, African boundaries stay permeable for certain researchers all through Africa, boundaries recognizing diverse sovereign conditions of the continent were drawn by pioneer powers without the interest of the African public and in manners that neglected to address their socio-social, political, and provincial characteristics. To relieve the troublesome impacts of self-assertive boundary development, the ECOWAS Protocol was created to eliminate all hindrances and deterrents to free movement and all member states pledged their help to the acknowledgment and full usage of the protocol. Studies have likewise archived the troubles going up against ECOWAS residents while getting across member states, proposing a disjuncture between the Protocol's expectations and viable experience (Okunade and Ogunnubi, 2018.).

The Economic Community of West African States (ECOWAS), formed in 1975 brings together countries in the region to facilitate regional economic integration. The operations include manufacturing, trade, telecommunications, electricity, agriculture, natural resources, commerce, monetary and financial concerns, with the goal of establishing a common trading bloc through economic cooperation, social matters as well as cultural issues. The aim is not only to create a trade union, but also to establish a "borderless region" supporting "free movement of persons" and the right of residency and establishment, as set out in the 1979 Free Movement Protocol.However, as this Protocol is not adequately applied, it makes it difficult for communities to travel freely and settle in ECOWAS countries, thus unleashing migration's potential for socio-economic growth in the region. To resolve this issue, the Centre for Migration Studies, the partner of MADE West Africa, aims to increase the capacity of civil society to affect intra- and intra-regional development and also at national level (MADE Network, n.d.). 
Journal DOI: www.doi.org/10.46654/ij.24889849

The variety of significance joined to protocol can be seen in legitimate and legal writings. Regardless of whether it is wrong or not, some lawful writings have utilized terms like convention, protocol, and treaty, in some cases agreements in a coterminous pattern. Frequently, it is the impact and not the title that is recognized in the eyes of the law (Ukaigwe, 2016).

States have been searching for more prominent methods of setting up coordinated efforts that can make more open doors for their populace while additionally extending agreeable relations with their neighbors. One such way is through territorial incorporation. Comprehensively characterized, Integration is a cycle of both developing and broadening connections among state actors. The provincial mix can for the most part be viewed as nation-states in a regional district deliberately conceding power to intergovernmental or supranational organizations in request to better their condition overall through collaboration. The destinations of the understanding could go from monetary to political to ecological, although it has normally appeared as a political economy activity where business interests have been the concentration for accomplishing more extensive socio-political and security goals, as characterized by governments (Opanike and Adewoju, 2015).

The main activities of the ECOWAS in the past decade has been to point out important issues and problems. These main issues are trade liberalism, free movement of persons, infrastructural development, and defense. Trade liberalism focuses on dismantling and removing barriers and obstacles in the sub-region. This activity took two stages before implementation. The transport and communication project began by the United Nations Economic Commission for Africa in 1961, but it was not until June 1981 that ECOWAS reached an agreement and began the said project. The focus was based on road programs, highway projects, and air transport in Sierra Leone, Benin, and Liberia. Furthermore, in 1985, ECOWAS had taken a deep interest in developing railways. In terms of telecommunications, INTELCOM was introduced in 1982 and became more developed in 1985 (Nwachukwu, 1991).

However, the free movements of persons by ECOWAS was a phase that affected the community in the first stage of integration. Nwachukwu (1991) further explained that it was signed at the second summit which involved several heads of states in Senegal on May 29, 1979. This protocol had three phases: First that citizens will be granted residence ad entry to any state within the community for 90 days without the use and requirement of a visa. While the other two phases will lead to the citizen's right to residence thereafter. Furthermore, the introduction of this protocol was greatly misinterpreted and it later ventured into massive socio-economic and political issues. Notwithstanding these issues, the community was not discouraged and so they came up with the second phase of the free movement protocol which was accepted after much difficulty. And since then, this protocol has been running smoothly with few complaints and difficulties.

However, this article's aim is to add to the existing body of knowledge on this subject and it will be centered on covid-19's effect on the protocol in terms of trade, free movement, ECOWAS support, and what can be done to ease the free movement and trade liberalization scheme. The study primarily adopts the qualitative research design which involves the use of secondary source of data, namely books, journals, articles, newspapers, conference papers, internet publications, among others. The rest of this study is divided into 4 sections namely, 
Journal DOI: www.doi.org/10.46654/ij.24889849

Article DOI: www.doi.org/10.46654/ij.24889849.s7557

management of the pandemic by West African states, covid 19's effect on the ECOWAS free movement protocol, recommendations, and concluding remarks.

\section{Management of the Pandemic by West African States}

The past of pandemics and infectious illness diseases is as ancient as mankind's life. The Novel Corona Virus, otherwise referred to as COVID-19, was first identified in the Chinese city of Wuhan in 2019. The pandemic has exploded through continents like flames, causing global health problems with the accompanying impacts on politics, markets, schooling, and lifestyles around the world. Despite the daily geometric rise in the number of reported illnesses and deaths, the devastating consequences of the pandemic forced the Health Organization (WHO) and political leaders around the world to initiate stringent steps. Travel bans, massive screening, vigorous contact tracing, determining the spread of the COVID-19 pandemic included interventions to curb the spread of the COVID-19 pandemic. Other efforts at mitigating the spread of the virus globally have been in the areas of collating data daily (BBC, 2020).

Battling or shortening the spread of the infection is especially troublesome in the West African sub-district due to the high pace of neediness and lack of education and obliviousness. Indeed, a few Africans wrongly accepted that the pandemic is "White-Man's Disease" that can't make due in the tropical district of Africa. Additionally, there were a few reports and falsehood that the infection can't avoid heat (Maclean, 2020), and thusly, it was accepted that it can't make due under warm temperature over 26-27 degrees. This caused numerous individuals to accept that the spread of the infection will be moderate on the chance that it will wander into Africa eventually because most nations are at normal temperatures of between 25-35 degrees. Amusingly, the infection has since tainted and executed Africans in their hundreds in different nations with Burkina Faso, Ghana Senegal, Nigeria, and the Gambia among others doing combating with mathematical day by day increment in figures of passing and diseases (Olagbaju et al, 2020).

More than 54 African countries have reported cases of COVID since the outbreak of the pandemic on the continent (Africa Center for Diseases Control, 2020.). Several more deaths have been recorded since the start of the outbreak. Millions have died in West Africa alone, and the sad part is, many still do not believe in the existence of the virus.

As of late, ECOWAS has likewise demonstrated solid authority in overseeing general wellbeing emergencies, including plagues like Ebola and the worldwide COVID-19 pandemic. The West African Health Organization (WAHO) and the ECOWAS Center for Disease Control (CDC) have helped states in accomplishing a planned provincial reaction to the Covid emergency (Medinilla, Byiers, and Apiko 2020).

\section{COVID - 19's Effect on ECOWAS Free Movement Protocol}

Following the first indications of COVID-19 in West Africa in March-April 2020, twelve nations authoritatively shut their borders. Other nations, for example, Ivory Coast, Senegal, and Benin did so by just restricting to basic intersections like appearances or takeoffs over land, and by embracing helpful corridors. Many of these measures depend on Article 4 of the 1979 Dakar Protocol of the Economic Community of West African States (ECOWAS) and Article 91 of the altered Treaty of the West African Economic and Monetary Union (known 
Journal DOI: www.doi.org/10.46654/ij.24889849

under its French abbreviation UEMOA), which approve states to restrict freedom of movement and home for reasons of public request, public security, or general wellbeing. The measures, in any case, have vigorously affected the legitimate system of free development of people all through the ECOWAS zone (Hamadou, 2020).

Hamadou (2020) described the free movement as the privilege of people to move to, get comfortable, and leave and return from one or more public regions freely. It establishes a sort of security which the state gives to the person, which also has the personality of an unalienable right. More explicitly, it has three parts: the option to enter, the option to dwell, and the privilege of foundation on the domain of ECOWAS member states. In West Africa, this right has recorded, monetary, and social legitimizations. It is set down in the writings of both the UEMOA and ECOWAS. This law and freedom have been embodied so deeply, West Africa never imagined it could be restricted or even stopped due to the rise and spread of a pandemic.

In Abuja, on the twelfth of June 2020, A virtual gathering of the ECOWAS organizing board of trustees of Ministers for transport, coordination's, free development, and exchange, set up inside the structure of the battle against the (COVID-19) hung on the twelfth of June 2020. Among others, the Ministers pondered on the harmonization of measures to encourage the launch of exchange and transport halls for hardware, clinical supplies, and helpful faculty engaged with the battle against COVID-19, the progression of fundamental products and related specialists; just as modalities for the execution of the arising Action. Establishing the pace for the gathering, the President of the ECOWAS Commission, H.E Jean-Claude Kassi Brou kept up that the event of the COVID 19 pandemic has constrained the ECOWAS Member States to set up intense hindrance measures (physical separating, isolate, the conclusion of schools, shops and places of love just as the aggregate or incomplete restriction on open vehicle in metropolitan zones). The present circumstance, he anyway noted, has negatively affected the economies of ECOWAS Member States and by ricochet, on the transport, exchange and intra-local area trades. President Brou proceeded, much like others in the community, has not been saved by the spread of COVID-19: "The circumstance of the pandemic as of eighth of June 2020 has the following: 41,934 affirmed cases, 829 passing, 19,181 relieved and 21,924 under treatment". He mourned that practically all areas of financial life have been influenced by the lull of monetary exercises, work misfortune, pay and income flight, increasing expenses, and so on. The Chairman of the Council of Ministers of Transport, Logistics, Free Movement and Trade and Minister of Aviation of the Federal Republic of Nigeria, Mr. Hadi Sirika who spoke to H E Muhammadu Buhari, President of the Federal Republic of Nigeria, and Champion for planning the reaction to COVID-19 in the area, made responsibilities towards guaranteeing that the rules for simplicity of exchange and administrations all through the pandemic time frame are set out and will be worked on (Mayaki, 2020).

For instance, Nigeria accounts for more than $60 \%$ of the sub-economy regions and remains the largest market for virtually all the 15 member states of the West African Economic Group (ECOWAS) (Karaki and Verhaeghe, 2017). This means that the other West African states can do virtually nothing without Nigeria's involvement. And if anything affects Nigeria's economy whatsoever, the rest of West Africa feels the blow or the effect. This also had a big effect on member states during the start of the pandemic. 
Journal DOI: www.doi.org/10.46654/ij.24889849

The second territorial condition, identified with the metro and lawful atmosphere in West African countries, lies in the nonappearance of the engagement of civil society and restricted public awareness with prosecution as a technique for rights implementation. In the setting of COVID-19, one may envision that domestic courts might have forestalled the summed up the infringements that we have seen. For sure, given the powerlessness of residents to bring claims under the steady gaze of the ECOWAS Court, domestic courts may appear to be extraordinarily skilled, from a certain point of view, of securing the basic character of the opportunity of development. However, the opportunities for domestic courts to investigate the sensibility and, the proportionality of COVID-19 based limitations are restricted by various political, institutional, also, lawful elements. The lack of a fundamental human rights mandate Courts, the non-application in most countries of the officially accepted monistic theory, NGOs and members of the public lead to the absence of a litigation tradition. Therefore, the responsibility of ECOWAS member states concerning measures violating rights was further hampered (Hamadou, 2020).

Since ECOWAS has lost so much during the pandemic, and all sectors have been affected including the free movement protocol, the leaders of member states should have come together, set up a meeting and discussed the issue. Also, political leaders do not have the right to cloud the decisions of domestic courts. This led to member states committing crimes in order to trade.

The resulting free movement restrictions have been especially detrimental to displaced persons, asylum seekers, and migrants, the concerns and vulnerabilities of whom are typically ignored. Only Ivory Coast has applied to the establishing of humanitarian corridors as an exception to the closing of borders to assist individuals or neighborhoods in need of immediate support. The restrictions in the case of refugees and asylum seekers, the concept of non-refoulment and a person's right to return to one's own are both controversial.The socalled "three-border region," where the boundaries of Burkina Faso, Mali, and Niger cross, is the so-called "three-border region." As a result of the state of emergency, the possibility of repossession of thousands of persons is very real. This could also mean that states may be violating the obligations of non-refoulment under article 33 of the Geneva Convention on Refugees. West African states have independently adopted steps relevant to COVID-19 that they deem acceptable in terms of their strategy and the urgency of the situation. Those interventions include the sanitary system, State of emergency, and Lockdown of closing of boundaries. This has posed serious problems and served as a threat to the free movement protocol. In West Africa, neither the closing of the borders nor the declaration of a state of sanitary emergency nor the curfews have been enforced. In embracing states, it helped to avert an uptick in COVID-19 cases and fatalities. Benin, by way of comparison, and has Chosen for versatile measures such as face masks and social distance, fewer deaths have been recorded than in Niger, Mali, Or Burkina Faso, resorting to border closures And the restriction of human liberty. Disconnecting this one between the steps taken and the goals followed, it is proposed that the answers are given in most of West Africa. They were not well-considered, balanced, contextualized, or organized for COVID-19. While the interventions implemented remain, in most situations, unsuccessful, they have produced at least two results that are not effective. Second, while such steps may be completely valid, they normally have Also within nations, expanded regulatory prerogatives to limit freedom of travel (Hamadou 2020.). 
For example, curfews in Nigeria were not adhered to and this led to the government taking vast measures to arrest offenders. Also, people were forced to wear nose masks and social gatherings were not stopped as political rallies were still on going.

From a social point of view, the mobility of West African societies is so natural the boundary closing or tight lockdown procedures cannot be reconciled with it. African states still do not Track both of their boundaries enough to be able to successfully enforce border closures (Hamadou, 2020.).

\section{Recommendations}

- ECOWAS needs to sit down and work on the free movement protocol to serve West Africa appropriately.

- ECOWAS should provide a conducive environment for free trade during the pandemic.

- ECOWAS needs to include free movement at the forefront of its affairs.

\section{Conclusion}

Without the free movement protocol, most West African member states are struggling to survive. Regardless of the presence of the pandemic, other measures can be takento avoid total downfall of economies in West Africa. 


\section{References}

Adeniran, A. (2012). Regional integration in the ECOWAS region: Challenges and opportunities.

Aduloju AA, O. A. (2015). ECOWAS Protocol on Free Movement and Trans-border Security in West Africa. Journal of Civil \& Legal Sciences, 04(03), 1.

https://doi.org/10.4172/2169-0170.1000154

Africa Centre for Disease Control (2020). Latest updates on the COVID-19 from Africa CDC. Available: https://africacdc.org/covid-19/

Available:https://www.who.int/emergencies/diseases/novel-coronavirus-2019/advicefor-

BBC News (2020). Coronavirus: Nigeria Confirm first case in Sub-Saharan Africa. Available:

Brunet-Jailly, Emmanuel. 2010. The State of Borders and Borderlands Studies 2009: A Historical View and a View from the Journal of Borderlands Studies. Eurasia Border Review.

Hamadou, A. (2020). Free Movement of Persons in West Africa Under the Strain of COVID19. AJIL Unbound, 114, 337. https://doi.org/10.1017/aju.2020.66

\section{https://www.bbc.com/news/world-africa-51671834}

Implementation of the ECOWAS Free Movement Protocol | MADE Network. (n.d.). Migration and Development Civil Society Network. Retrieved January 25, 2021, from https://madenetwork.org/implementation-ecowas-free-movement-protocol

Karaki, K, and Verhaeghe, E., 2017. "Understanding ecowas trade policy and facilitation advancing economic integration one hurdle at a time." In the European center for development policy management background paper. P. 15.

Maclean, R. (2020). African braces for Coronavirus, but slowly. The New York Times.

Mayaki, H. (2020, June 13). ECOWAS Ministers Validate Reports on Ease of Business and Coronavirus Control | Economic Community of West African States (ECOWAS). ECOWAS. https://www.ecowas.int/ecowas-ministers-validate-reports-on-ease-ofbusiness-and-coronavirus-control/

Medinilla, A., B. Byiers, and P. Apiko. 2020. "African Regional Responses to COVID-19." Discussion Paper No. 272, European Centre for Development Policy Management, Maastricht.

Nwachukwu, I. (1991). Nigeria and the ECOWAS since 1985: Towards a Dynamic Regional Integration. Fourth Dimension Publications Ltd. 
Okunade, S. K., \&Ogunnubi, O. (2018). A “Schengen” agreement in Africa? African agency and the ECOWAS protocol on free movement. Journal of Borderlands Studies, 1-19.

Olagbaju, O. O., Awosusi, O. E., \&Shaib, O. E. (2020). COVID-19 Induced Changes on Lifestyles Education and Socio-Economic Activities in the West African States: Recovery Strategies for Post Pandemic Era. International Journal of World Policy and Development Studies, 6(4), 38-43.

public/myth-busters

Rumors and Facts (2020). Rumors and facts on COVID-19. (2):

Ukaigwe, J. (2016). ECOWAS Law and National Laws. In ECOWAS Law (pp. 52). Springer, Cham. 